\title{
ゼラチンゲルに関する研究 (I) \\ Studies on Gelatin Gel (I)
}

\author{
ゼラチンと寒天の混合温度のゲルの性質に対する影響 \\ Effect of Temperature at Mixing \\ Gelatin and Agar on the Properties of Gel
}

（昭 和 40 年 4 月 23 日受理）

安松 克 治 藤 田 栄 一 郎
(Katsuharu Yasumatsu)
(Eiichiro Fujita)

The effect of the temperature on the properties of the gelatin-agar gel at making the mixture of gelatin and agar was investigated.

The yield value of gelatin-agar gel depended only on the temperature at which gelatin was mixed with agar. Thus after mixing the both components at a certain temperature, the yield value was not affected by any heat treatment below $90^{\circ} \mathrm{C}$.

The component which is influenced by the mixing temperature is not the gelatin but the agar.

緒言

一般にゲル状食品は甘味, 酸味, 香料などで調味され ているが，口の中でゲルが解けなければこれら調味剤の 味は全く感じられない。したがってゲル状食品の融点は 体温に近いことが望ましい。一方ゲルの保存は低温で行 なえても，輸送などを考えると夏期の室温に数時間放置 しても解けない方が望ましい。

ところでゼラチンの融点はゼラチン濃度によって変動 するが $30^{\circ} \mathrm{C}$ 付近であり, しかも温度による硬さの变化 がきわめてはげしい。すなわち冷蔵庫に放置すると硬く なりすぎてまずいし，夏期室温に放置すると解けてしま う。寒天はその点硬さの変動は少ないが, 融点が70〜80 ${ }^{\circ} \mathrm{C}$ でロの中ではとけない。

そこで夏期の室温 $\left(30 \sim 33^{\circ} \mathrm{C}\right)$ では解けないで，体温 ではたやすくとけるゲル状食品を得る目的でゼラチン液 と寒天液を混合する温度と，ゲルの解けやすさ硬さの関 係について詳練に研究した。そしてゼラチンと寒天の混 合温度がゲルの各種の性質に極めて大きな影響をすつこ とを見出した。

\section{実 験 方 法}

1. ゲルの解けやすさの測定法

ゲルの触点の測定方法は種々考案されているが1)，本 研究では口の中での解けやすさを知る目的で, $37^{\circ} \mathrm{C} て ゙$
解ける速さを次の方法で測定した。

すなわちゼラチンと寒天の混合夜を第 1 図のよ5なガ ラス管中に流し込み，氷水中で 1 時間冷却後 12 時間 $9^{\circ} \mathrm{C}$ の電気冷蔵庫中に放圆, ガラス管中でゲル化した後その 上にベアリングの玉を入れ第1図（a）のようにする。 これを $37^{\circ} \mathrm{C}$ の恒温槽に入れるとガラス管中のゲルは解 けてベアリングの玉は沈む。恒温槽に入れてから（b ) 図のような状態になるまでの時間を測定してゲルの解け やすさの目安とした。

第1困 ゲルの解けやすさの測定法

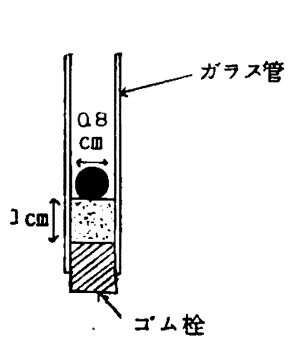

(a)

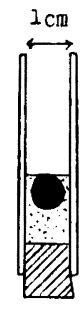

(b)
2. ゲルの硬さの測定法

ヨーグルト用のカードテンションメーターを使用し た。

この装置はゲルの降伏値を測定するもので, 何 $\mathrm{g}$ の力 で押えたときゲルの型がくずれるかを測定する。測定值 
はノ/押える円板の面積, すなわち $\mathrm{dyne} / \mathrm{cm}^{2}$ で示さ れ,この值の大きいすの程硬い。

3. ゲルの調製法

ゼラチン $1.6 \mathrm{~g}$ を約 $30 \mathrm{cc}$ の水に入れて 1 時間放㯰後 $50^{\circ} \mathrm{C}$ 以下て加温して溶かし水を加えて $50 \mathrm{cc}$ とする。 一方寒天 $0.4 \mathrm{~g}$ を約 $45 \mathrm{cc}$ の水に入れて 30 分放固後加熱 する。沸騰してから 30 分間 $90 \sim 95^{\circ} \mathrm{C}$ に保って完全に溶 かし, ガーゼで汇過熱水を加えて $50 \mathrm{cc}$ とする。両液を 冷却し液温が目的とする温度になったときに混合する。 水水中で 1 時間冷却後 $9^{\circ} \mathrm{C}$ の電気 冷藏庫に放置してゲ ルとする。本研究では調味せずに各種測定に用いた。

\section{実 験 結 果}

1. 混合温度と硬さ, 解けやすさの関係

混合時の寒天, ゼラチン液の温度を变えた場合の硬 さ, 解けやすさの变化を第 2 四に示す。

第 2 図 ゼラチン液と寒天液の混合温度の, ゲル の硬さ, 解けやすさに対する影響

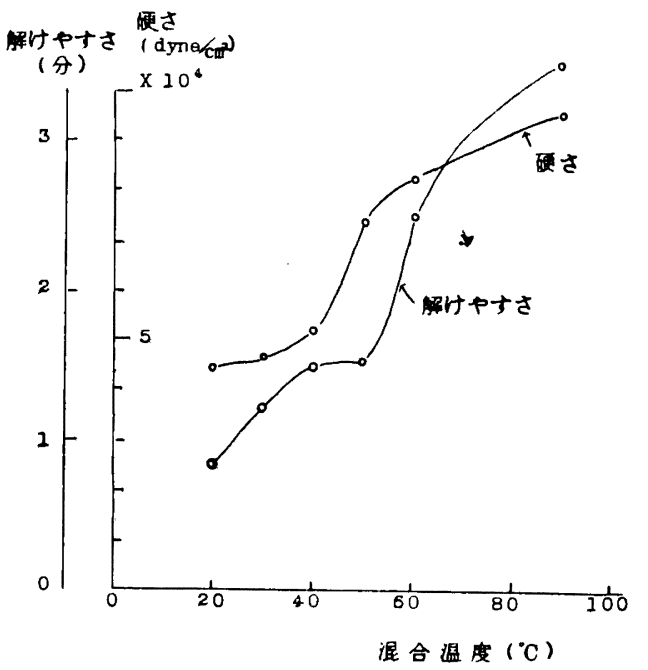

このように混合温度の影響は非常に大きい。

2. 混合温度に影響されるゲル中の成分

ゲルをつくっている寒天とゼラチンのうち，いずれが 混合温度の影響を受けるかを検討した。

すなわち一定温度の $0.8 \%$ 寒天液にそれと同じ温度 の同量の水を加えて混合した後冷却してゲルを作った。 ゼラチンについても同様のことを行なった。結果を第 3 図に示す。

このように混合温度の影響を受けるのは寒天であって ゼラチンと寒天の混合夜のゲルの場合すその解けやすさ は混合時の寒天液の温度によって定まる。

3. 混合後の温度変化による解けやすさの変化
第3図 混合温度に影響されるゲル中の成丹

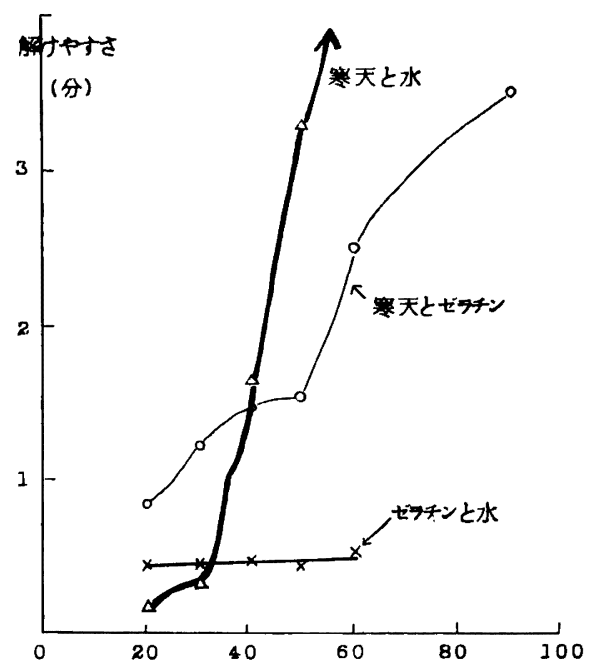

湦合温度(

ゼラチン液と寒天液を一定温度で混合後その混合液の 温度を上下した場合のゲルの解けやすさの変化を検討し た。

すなわちゼラチン液と寒天液を $40^{\circ} \mathrm{C}$ あるいは $30^{\circ} \mathrm{C}$ で混合し，混合液をアミログラフ（デンプンの絹化温度 第 4 図 混合後の温度変化とゲルの解け やすさの関係

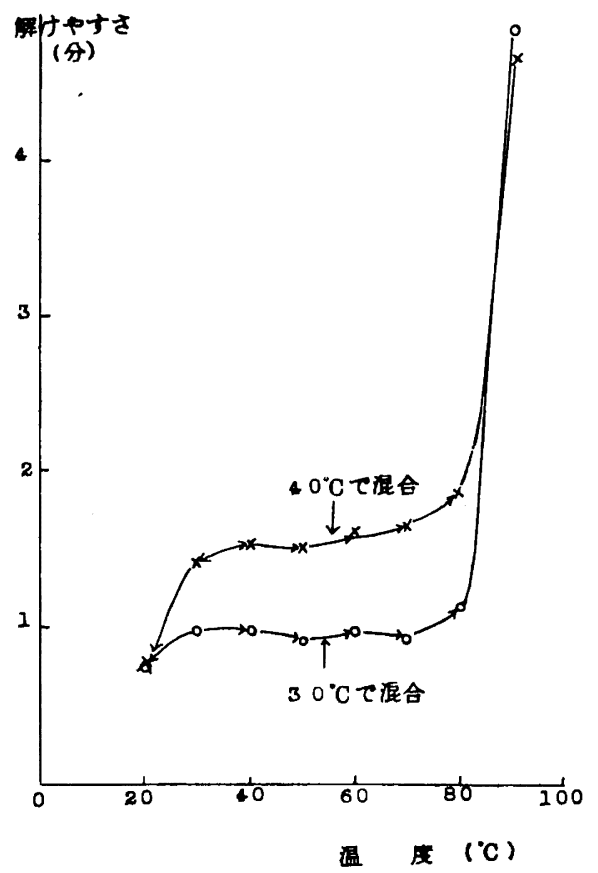




\section{第 18 巻 第 4 号}

て測定する一種の回転粘度計）に入れて 1 分間 $1.5^{\circ} \mathrm{C}$ の速さで温度を上䄯あるいは下降させ $40,50 ， 60,70$, 80, $90^{\circ} \mathrm{C}$ になったとき一定量をとり冷却してゲル化し 解けやすさを測定した。その結果を第 4 図に示す。

また第 5 図は $30^{\circ} \mathrm{C}$ で混合後 1 分間 $1.5^{\circ} \mathrm{C}$ の速さで 温度を上升させ， $40^{\circ} \mathrm{C}$ になった後その温度で 1 時間か きまぜ，同じ速度で温度を上年させ $50^{\circ} \mathrm{C} て ゙ 1$ 時間放䁌 一この操作をくり返し $90^{\circ} \mathrm{C}$ まで上年， $90^{\circ} \mathrm{C} て ゙ 1$ 時間 かきまぜた後 1 分間 $1.5^{\circ} \mathrm{C}$ の速さで令却した場合のゲル の解けやすさの変化を示した。

\section{第 5 因 混合後の温度变化とゲルの解けや すさの関係}

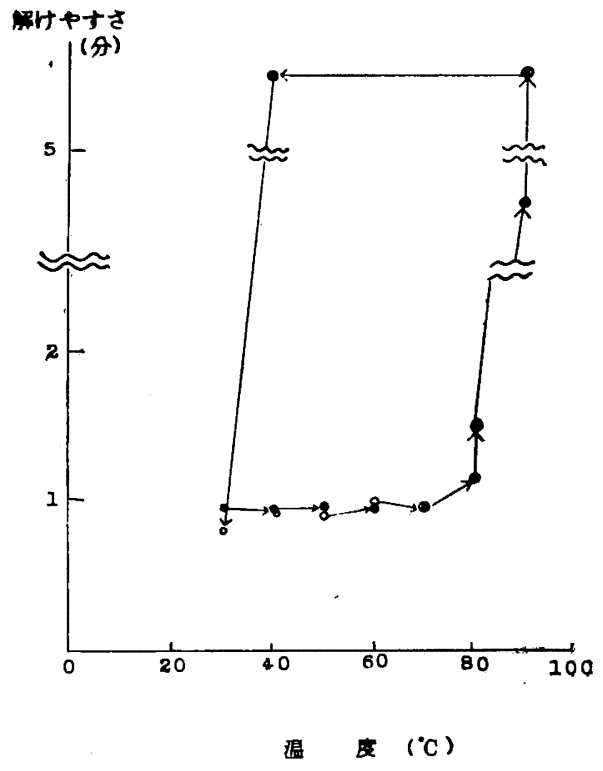

・その温度に達した直後 ○その温度で1時间倳汼後

この第 4,5 図に示されるように，ゼラチンと寒天の 混合時の温度が重要で，混合後 $80^{\circ} \mathrm{C}$ までは温度をあげ ても解けやすさは变わらない。すなわち $30^{\circ} \mathrm{C} て ゙$ 混合し たものは，その後温度をあげても混合時とおなじ解けや

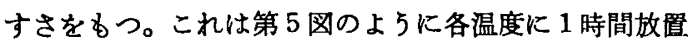
してる同様である。

しかし $90^{\circ} \mathrm{C}$ 以上にすると寒天だけのゲルのように， $37^{\circ} \mathrm{C}$ では解けなくなる。

\section{考察}

ゼラチンと寒天の混合時の温度がゲルの性質に影響を 与えることは興味あることである。その原因機構につい てはさらに検討が必要であるが，現在までの結果から一 応次のように推定している。

ゼラチンや寒天のような高分子物質の混合物のゲルの
硬さには，゙゙ル中の両者の分散の度合が大きな影響をも つと考えられる。たとえばゼラチンと寒天の混合物のゲ ルが第6因（a）のようになっているか（b）のよ5で あるかによって硬さは変わるであろう。（a）は Gerngros ら)により (b) は Eirich と Mark ${ }^{\text {s) }}$ とによりゴ ムのトルェン溶液の微分子形として提案された模式図を 利用したすのであって，Reiner') が指摘しているょ5に （b）の方が熱によってたやすく形がくずれると考兄ら れる。すなわち（a）の方はゼラチンが解けても寒天が 骨格をつくっているからゲルの形はくずれないであろ 5。

第6図 寒天とゼラチンの混合ゲルの構造

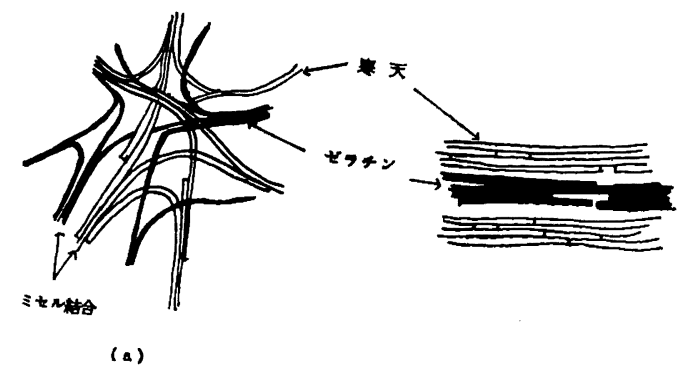

(b)

一方 Boedtker, Doty ${ }^{5)}$ によると， $40^{\circ} \mathrm{C}$ 以上でゼラ チンは分子会合を起さないか，それ以下の温度で分子 会合してミセル状に溶けていると考えられる。寒天につ いても夜温により溶解の状態が变わることは当然考えら れ，ミセル状に溶けているるのを混合すると（b) 四の ようなゲル構造ができるであろう。両者を混合するとき の温度すなわち溶解状態の差によって生成するゲル構造 が異なり，゙゙ルの融点に差ができるのであろう。このよ 5に考えると第 4,5 図の結果は次のよ 5 に推測しうる。

すなわちゼラチンと寒天の混合夜は $90^{\circ} \mathrm{C}$ 以下でかき まぜてる混合時のミセル構造をそのまま保っているが， $90^{\circ} \mathrm{C}$ 以上になって始めて寒天がミセル構造をくずし単 分子状に溶け自由な立体配置をとる。したがってその液 を冷却してできるゲルは寒天が骨格となるのであろう。

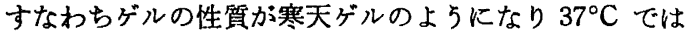
とけなくなるのであろう。

一方 $90^{\circ} \mathrm{C}$ で 1 時間かきまぜたものを冷却する場合， $40^{\circ} \mathrm{C}$ までは $90^{\circ} \mathrm{C}$ の状態と変わらないが， $30^{\circ} \mathrm{C}$ にする ときわめてやわらかいゲルとなる。これはこの混合液の ゲル化温度が 30〜 40 $\mathrm{C}$ にあることを示するのである。

すなわちゲル化温度以下の $30^{\circ} \mathrm{C}$ では立体的なゲル模 造が発達し始めるが，かきまぜているためそのゲル構造 が破壊され強固なゲルができないと考えられる。 


\section{総括}

ゼラチン液と寒天液の混合温度がゲルの解けやすさ, 硬さに扰よほす影響について検討し，つぎのようなこと を明らかにし得た。

1. ゼラチン液と寒天液の混合温度がゲルの硬さに大 きな影響をすつ。

2. 混合時の温度が重要であって混合後 $90^{\circ} \mathrm{C}$ 以下の 温度に上䄯しても，ゲルの解けやすさには影響しな い。

3. 混合温度の影響をうけるゲルの硬さ，解けやすさ を支配するのは，主として寒天である。
終わりに,ご指導をたまわった京都大学教授満田久獣 博士に心から感謝いたします。また，本発表を許可され た研究開発本部長立岡末雄博士ここ助言をたまわった， 間中次郎工業研究所長に深謝します。

\section{文献}

1）日本工業規格 K6503

2) O. Gerngros et al.: Zeit. Phys. Chem., B10, 371 (1930)

3) F. Eirich et al.: Naturw., 15, 1 (1936)

4) M. Reiner: Deformation and Flow, H.K. Lewis \& Co. Ltd., London (1949)

5) H. E. Boedtker \& P. Doty: J. Phys. Chem., 58, 968 (1954)

(武毘薬品工業株式会部工社)

\section{DNP誘導体化によるアミノ酸の分離}

蛋白質構成アミノ酸をDNP化し，メチオニン，ロイ シン (イソロイシン), フェニルアラニン, オルニチン, リジン, チロシンの各誘導体を分配カラムクロマトグラ フィー法により分離した。このクロマトグラフィー用の カラムの調製の際, ガラス管とディスクとの内径の差 が0.06cm あることが最も望ましい。その理由は明らか ではないがディスクが管に密着していると保持体が均一 に充てんされないためと思われる。クロマトグラフィー を高速 $\left(1 \mathrm{ml} / \mathrm{min} / \mathrm{cm}^{2}\right)$ でおこならので, DNP アミノ
酸帯が広がらず分離がよい。 $\mathrm{R}$ 值は0.2 0.7の籍囲内に あり, 溶出に要する時間は 1 時間以内である。（表 1 )

The Isolation of Amino Acids from Mixtures as $t^{\text {heir N-2, 4-Dinitrophenyl Derivatives. }}$

Methionine, Leucine, Phenylalanine, Ornitin, Lysine and Tyrosine.

by Matheson, N. A. : Biochem. J., 94, p. 513 517 (1965)

（剣持） 